\title{
Impact of sociodemographic variables on executive functions
}

\author{
Kenia Repiso Campanholo ${ }^{1}$, Izadora Nogueira Fonte Boa ${ }^{1}$, Flávia Cristina da Silva Araujo Hodroj', \\ Glaucia Rosana Benute Guerra' ${ }^{1}$ Eliane Correa Miotto², Mara Cristina Souza de Lucia ${ }^{1}$
}

\begin{abstract}
Executive functions (EFs) regulate human behavior and allow individuals to interact and act in the world. EFs are sensitive to sociodemographic variables such as age, which promotes their decline, and to others that can exert a neuroprotective effect. Objective: To assess the predictive role of education, occupation and family income on decline in executive functions among a sample with a wide age range. Methods: A total of 925 participants aged 18-89 years with 1-28 years' education were submitted to assessment of executive functions using the Card Sorting Test (CST), Phonemic Verbal Fluency (FAS) Task and Semantic Verbal Fluency (SVF) Task. Data on income, occupation and educational level were collected for the sample. The data were analyzed using Linear Regression, as well as Pearson's and Spearman's Correlation. Results: Age showed a significant negative correlation $(p<0.001)$ with performance on the CST, FAS and SVF, whereas education, income and occupation were positively associated $(p<0.001)$ with the tasks applied. After application of the multivariate linear regression model, a significant positive relationship with the FAS was maintained only for education $(p<0.001)$ and income $(p<0.001)$. The negative relationship of age $(p<0.001)$ and positive relationship of both education $(p<0.001)$ and income $(p<0.001$ and $p=0.003)$ were evident on the CST and SVF. Conclusion: Educational level and income positively influenced participants' results on executive function tests, attenuating expected decline for age. However, no relationship was found between occupation and the cognitive variables investigated.
\end{abstract}

Key words: aging, socioeconomic factors, executive function.

\section{IMPACTO DAS VARIÁVEIS SOCIODEMOGRÁFICAS NAS FUNÇÕES EXECUTIVAS}

RESUMO. Funções executivas regulam o comportamento humano e permitem ao indivíduo interagir e agir no mundo. Elas são sensíveis a variáveis sociodemográficas como a idade, que promove seu declínio, e a outras que podem ter ação neuroprotetora. Objetivo: Avaliar o papel preditivo da escolaridade, atividade ocupacional e renda familiar sobre 0 declínio das funções executivas em uma amostra de ampla variação de idade. Métodos: 925 participantes saudáveis com idades de 18 a 89 anos e escolaridade de 1 a 28 anos foram submetidos ao exame de funções executivas com uma Tarefa de Classificação de Cartas (TCC) e de Fluência Verbal nominal (FVN) e semântica (FVS). Foram obtidas a renda, atividade ocupacional e escolaridade da amostra. Os dados foram analisados com Regressão Linear, Correlação Pearson e Spearman. Resultados: Idade apresentou correlação significativa $(p<0,001)$ negativa com 0 desempenho em TCC, FVN e FVS, enquanto educação, renda e ocupação se relacionaram de forma positiva $(p<0,001)$ com as tarefas utilizadas. Após modelo de regressão linear multivariada, apenas educação $(p<0,001)$ e renda $(p<0,001)$ mantiveram relação significativa positiva com FVN. A relação negativa da idade $(p<0,001)$ e positiva de educação $(p<0,001)$ e renda $(p<0,001$ e $p=0,003)$ foi evidente em TCC e FVS. Conclusão: Escolaridade e renda influenciaram positivamente os resultados dos participantes nos testes de função executiva, tendo um efeito contrário ao declínio esperado para a idade. Por outro lado a ocupação não manteve relação com as variáveis cognitivas.

Palavras-chave: envelhecimento, fatores socioeconômicos, função executiva.

\section{INTRODUCTION}

Executive functions (EFs) regulate human ties that allow individuals to interact and act intentionally in the world, i.e. based on the creation, supervision and readaptation of goals. ${ }^{1,2}$ This involves the formulation of a plan of action and in doing so considers

\footnotetext{
This study was conducted at the Hospital das Clínicas da Faculdade de Medicinada da Universidade de São Paulo, São Paulo SP, Brazil.
}

'Division of Psychology, Hospital das Clínicas da Faculdade de Medicina da Universidade de São Paulo, São Paulo SP, Brazil. ²Department of Neurology, Hospital das Clínicas da Faculdade de Medicina da Universidade de São Paulo, São Paulo SP, Brazil.

Kenia R.Campanholo.Av. Min.Petrônio Portela,2001/222E-02802-120SãoPauloSP-Brazil.E-mail:krcampanholo@yahoo.com.br/izadoranogfb@hotmail.com Disclosure: The authors report no conflicts of interest. 
previous individual experiences and the environmental constraints imposed, allowing the devising of an appropriate sequence of actions to execute the initial plan. ${ }^{1}$

The executive functions involve the frontal lobe, particularly the pre-frontal cortex. ${ }^{3}$ The development of EFs commences in the first year of life, and develops most between 6 and 12 years of age. ${ }^{4}$ After complete maturation, the EFs remain stable until the onset of senescence, ${ }^{3}$ being one of the first functions affected by the aging process, particularly working memory ${ }^{5}$ and information processing speed. ${ }^{6}$ With advancing age, hemodynamic changes in the whole brain can be expected, where these are most marked in the frontal, temporal and occipital lobes. ${ }^{7}$ Moreover, age-dependent frontal lobe atrophy, ${ }^{8}$ as well as reduced connectivity between frontal regions and subtentorial territories, has also been described. ${ }^{8,9}$

However, in order to better understand the relationship between advancing age and decline in executive functions, differences in the aging process due to cultural and sociodemographic variability in the population must be elucidated. ${ }^{10,11}$ Exposure to factors such as reading habits, ${ }^{12}$ cognitively-demanding activities, ${ }^{13}$ and especially higher educational levels, ${ }^{11,12,14-16}$ influence base cognitive capacity. These stimuli help maintain effective cognitive performance despite aging or the onset of brain pathologies, thus establishing a neuroprotective relationship. ${ }^{14,17-19}$

Two sociodemographic processes and their influences on cognition are less investigated in the literature, namely, previous occupation and socioeconomic level, where the latter is an item constituting the human development index..$^{22}$

Healthy elderly engaged in life with more complex occupational tasks have better performance on cognitive testing, irrespective of gender, age or educational level. ${ }^{13}$ The hypothesis for these findings is that occupational activities of a high technical level induce mental stimulation through the practice and strengthening of cognitive functions. ${ }^{13,23}$

With regard to the economic aspect, its impact on cognitive development from childhood is clear, since brain development is positively correlated with higher family income. ${ }^{24}$ In adults, greater scores on screening tests correlate with higher incomes. ${ }^{25}$ On a broader level, socioeconomic status is considered indicative of health, and is also associated with a lower tendency for cognitive decline and depression. ${ }^{26}$

However, the cited studies remain limited and are largely based on screening tests. This scenario prompted the present study investigating executive functions sensitive to aging ${ }^{3}$ and their relationships with sociodemographic variables by applying tests sensitive to EFs. Two tasks are often employed in EF assessments. The first is the card sorting test, ${ }^{27}$ which requires recruitment of visual EFs related to categorization, working memory and mental flexibility. ${ }^{28}$ The second is phonemic and semantic category verbal fluency tasks, ${ }^{29,30}$ which require greater recruitment of verbal $\mathrm{EFs}$ related to working memory and processing speed, ${ }^{31}$ in addition to language resources such as lexical access. ${ }^{32}$

The role of EFs as regulators of human behavior renders it important to understand how these abilities are maintained during adult life and aging, and particularly the impact of sociodemographic factors on these functions. ${ }^{21}$ Understanding the relationship between these variables and EFs can help promote improvements in quality of life. Therefore, the objective of the present study was to assess the predictive role of sociodemographic variables (educational level, occupation and family income) on EF decline in a sample with a wide age range.

\section{METHODS}

Participants. A total of 1,310 Portuguese-speaking natives (Brazil) aged 18-89 years with 1-28 years education were recruited. Individuals with no motor or sensory deficits preventing execution of the tasks, no previous or current history of neurological or psychiatric diseases, and not in use of psychotrophic drugs were initially included.

Of the initial sample, 339 subjects with scores below established cut-off medians for educational level (20 for illiterates; 25 for 1-4 years; 26.5 for 5-8 years; 28 for 9-11 years and 29 for higher education) on the MiniMental State Exam (MMSE) ${ }^{32}$ were excluded, comprising 8 for reporting symptoms of anxiety and depression on the Hospital Anxiety and Depression Scale (HADS) ${ }^{33}$ and 38 for having estimated intelligence quotient $<80$. Thus, 925 participants were included in the study.

Instruments and procedures. Education was determined based on the number of years' education counted up until the last full year of school or university attended. Academic years studied due to repeats were not counted.

Occupations were classified according to the International Standard Classification of Occupations (ISCO) into the 10 major groups ( 0 - armed forces, military police and firemen; 1 - senior officials, legislators, chief executives and managing directors; 2 - science and arts professionals; 3 - technicians and associate profession- 
als; 4 - clerical support workers; 5 - service workers; market and shop salespersons; 6 - Agricultural, forestry, game and fishery workers; 7 and 8 - Trades workers and operators; and 9-maintenance and repair workers. ${ }^{34}$ For the purposes of the present analysis, these 10 major groups were consolidated into 3 categories: General Services (ISCO 4-9), Technical Professionals (ISCO 3) and University Professionals (ISCO 2). The groups ISCO 0 and 1 were distributed amongst these 3 categories according to the educational level required for the job performed. A fourth category was added for this study containing individuals Not in Formal Employment because they were retired, unemployed, students or performing occupational tasks exclusively for their family (homemakers).

Income was calculated based on the number of minimum monthly wages (MWs) received, categorized into five groups: <3 MWs; 4-6 MWs; 7-9 MWs; 10-12 MWs; or $\geq 13$ MWs. The income variable was based on family income (sum of incomes of all dwellers in the same household) as opposed to individual income.

After signing the Free and Informed Consent Form approved by the Ethics Committee of the University of São Paulo School of Medicine (CAPPesq 086/06), the participants were submitted to the semi-structured interview for collection of sociodemographic data and medical history. The inclusion and exclusion criteria were checked by applying the cognitive screening (MMSE) and mood (HADS) ${ }^{33}$ scales, and the assessment of estimated intelligence quotien $t^{35}$ based on the Vocabulary and Matrix Reasoning subtests of the Wechsler Adult Intelligence Scale (WAIS-III). ${ }^{36}$

For assessing EFs, two tasks associated with activation of pre-frontal regions were employed.

Card Sorting Test (CST)(27) - The participant has to sort 48 cards according to the number, shape and color of their printed stimuli. Feedback was given on each attempt regarding the accuracy of the response. In this study, only the number of complete categories was scored. Performing the task requires the formation of strategies, planning and mental flexibility and thus activates the dorsolateral (DLPFC), ventrolateral (VLPFC) and anterior cingulate (ACC) $)^{37}$ cortex regions.

Phonemic Verbal Fluency (FAS) and Semantic Verbal Fluency (SVF)(30) - For the FAS, the participant must say as many words as possible in 60 seconds starting with a given letter, abiding by two rules: do not use proper nouns or words with suffixes. The letters used were F, A and S, with score taken as the sum of words produced using the three letters. For the SVF, the participant has to say as many animal names as possible in 60 seconds, with score taken as the sum of the words produced in this category. Letter and semantic category verbal fluency tasks require monitoring of rules and inhibition of inadequate responses, besides language abilities. Therefore, these tasks activate temporal regions and the superior anterior pre-frontal region. ${ }^{38}$ It is important to note that the both the FAS and the SVF directly depend on processing speed, since they are tests which assess the number of responses uttered in a short timeframe, where the examinee must attempt the highest production as possible while abiding by the rules given. ${ }^{30}$

Statistical analysis. All statistical analyses were performed using the statistical software SPSS V20 for Windows 8.1. For descriptive statistics, mean was used as the measure of central tendency and standard deviation as the measure of dispersion. Categorical data were expressed as relative and absolute frequency measurements.

Pearson's or Spearman's correlation was used to determine the relationship between the sociodemographic variables and the results on the executive function tests. Variables showing correlation with $\mathrm{p} \leq 0.01$ were included in the Multivariate Linear Regression Model, with significance set at the level of $\mathrm{p} \leq 0.05$.

\section{RESULTS}

The socioeconomic and demographic characteristics of the study sample are given in Table 1. Notably, the proportion of participants with very low educational level was small, where 2 participants had 1 year of education, 4 had 2 years and 14 had 3 years' education. Scores by participants on the FAS, SVF and CST are given in Table 2.

The correlations between the sociodemographic variables and EF tests are given in Table 3. The results of these analyses revealed a negative relationship between age and the cognitive variables, suggesting poorer results on the tests applied with increasing age. A positive relationship was found between the cognitive variables and the measurements of income, educational level and occupation, suggesting that an increase in one of these variables was concomitant with increase in the others.

Based on these results, a multiple linear regression model was constructed to assess the effects of education, income and occupation on the scores for the EF tasks. The results of the analysis are given in Table 4.

The analysis revealed that the significant positive relationship of education and income with the FAS Sum of Letters remained. Income and education explained $34 \%$ of the results on the FAS Sum of Letters. 
Table 1. Sample characteristics.

\begin{tabular}{|c|c|c|}
\hline \multicolumn{2}{|c|}{ Demographic and cognitive screening variables } & \multirow{2}{*}{$\begin{array}{c}\text { Total sample }(\mathbf{n}=\mathbf{9 2 5}) \\
324(35 \%)\end{array}$} \\
\hline Gender & Male & \\
\hline & Female & $601(65 \%)$ \\
\hline \multirow[t]{3}{*}{ Education } & $1-8$ years $(\mathrm{n}(\%))$ & $306(33 \%)$ \\
\hline & $9-11$ years $(\mathrm{n}(\%))$ & $202(22 \%)$ \\
\hline & $>11$ years $(\mathrm{n}(\%))$ & $417(45 \%)$ \\
\hline \multirow[t]{4}{*}{ Age } & 18-39 years (n (\%)) & $447(48 \%)$ \\
\hline & 40-59 years ( $\mathrm{n}(\%))$ & $307(33 \%)$ \\
\hline & $60-69$ years $(\mathrm{n}(\%))$ & $120(13 \%)$ \\
\hline & $>69$ years $(\mathrm{n}(\%))$ & $51(6 \%)$ \\
\hline \multirow[t]{5}{*}{ Income } & 1-3 minimum wages $(\mathrm{n}(\%))$ & $270(29 \%)$ \\
\hline & 4-6 minimum wages $(\mathrm{n}(\%))$ & $239(26 \%)$ \\
\hline & 7-9 minimum wages $(\mathrm{n}(\%))$ & $102(11 \%)$ \\
\hline & 10-12 minimum wages (n (\%)) & $127(14 \%)$ \\
\hline & >12 minimum wages $(\mathrm{n}(\%))$ & $187(20 \%)$ \\
\hline \multirow[t]{4}{*}{ Occupation } & Not in formal employment (n (\%)) & $237(26 \%)$ \\
\hline & General Services (n (\%)) & $244(26 \%)$ \\
\hline & Technical-level Professionals (n (\%)) & $107(12 \%)$ \\
\hline & University-level Professionals (n (\%)) & $337(36 \%)$ \\
\hline \multirow[t]{4}{*}{ Mood and cognitive screening } & Intelligence Quotient (M(SD)) & $103.50(12.45)$ \\
\hline & Anxiety symptoms (M(SD)) & $4.45(2.13)$ \\
\hline & Depression symptoms (M(SD)) & $3.39(2.29)$ \\
\hline & Mini-Mental State Exam (M(SD)) & $28.99(1.21)$ \\
\hline
\end{tabular}

M: mean; SD: standard deviation.

Table 2. Scoring of participants on CST, FAS and SVF tests.

\begin{tabular}{|c|c|c|c|c|c|c|c|}
\hline \multirow[b]{3}{*}{ Age } & & \multicolumn{6}{|c|}{ Years' education } \\
\hline & & \multicolumn{2}{|c|}{1 to 8} & \multicolumn{2}{|c|}{9 to 11} & \multicolumn{2}{|c|}{$>11$ years } \\
\hline & & $\mathbf{N}$ & $M(S D)$ & $\mathbf{N}$ & M (SD) & N & M (SD) \\
\hline \multirow[t]{3}{*}{$18-39$ years } & FAS Sum of letters & 54 & 28.28 (8.61) & 58 & $31.76(8.21)$ & 137 & 41.56 (9.04) \\
\hline & SVF & 54 & $14.48(3.05)$ & 58 & $17.55(4.49)$ & 137 & $21.40(4.60)$ \\
\hline & CST & 54 & $3.96(1.74)$ & 58 & $4.93(1.39)$ & 137 & $5.67(0.79)$ \\
\hline \multirow[t]{3}{*}{$40-59$ years } & FAS Sum of letters & 72 & $31.93(9.41)$ & 49 & $32.33(6.85)$ & 77 & 43.06 (10.63) \\
\hline & SVF & 72 & $14.58(3.48)$ & 49 & $15.86(4.10)$ & 77 & $20.43(4.06)$ \\
\hline & CST & 72 & $4.15(1.81)$ & 49 & $4.78(1.56)$ & 77 & $5.48(1.26)$ \\
\hline \multirow[t]{3}{*}{$60-69$ years } & FAS Sum of letters & 47 & $27.00(7.81)$ & 41 & $34.22(8.11)$ & 83 & $40.31(10.55)$ \\
\hline & SVF & 47 & $12.89(3.66)$ & 41 & $15.98(3.47)$ & 83 & $18.63(4.18)$ \\
\hline & $\overline{\mathrm{CST}}$ & 47 & $4.40(1.51)$ & 41 & $5.05(1.27)$ & 83 & $5.52(0.88)$ \\
\hline \multirow[t]{3}{*}{$70-89$ years } & FAS Sum of letters & 34 & $32.21(7.45)$ & 31 & $33.65(7.81)$ & 71 & $39.66(9.57)$ \\
\hline & SVF & 34 & $14.03(2.44)$ & 31 & $15.00(3.77)$ & 71 & $19.18(5.57)$ \\
\hline & CST & 34 & 4.56 (1.71) & 31 & $4.13(1.43)$ & 71 & $5.32(1.16)$ \\
\hline
\end{tabular}

CST: Card Sorting Test; FAS: Phonemic Verbal Fluency Test; SVF: Semantic Verbal Fluency Test; M: mean; SD: standard deviation. 
Table 3. Correlation between executive functions and sociodemographic variables.

\begin{tabular}{lccccc}
\hline & & Age $^{\star *}$ & Years' education $^{\star *}$ & Occupation $^{\dagger}$ & Income $^{\dagger}$ \\
\hline FAS Sum of letters & $\mathrm{r}$ & $-0.113^{*}$ & $0.576^{*}$ & $0.410^{*}$ & $0.410^{\star}$ \\
\cline { 2 - 6 } & $\mathrm{p}$ & $<0.001$ & $<0.001$ & $<0.001$ & $<0.001$ \\
\hline SVF & $\mathrm{r}$ & $-0.268^{*}$ & $0.553^{\star}$ & $0.446^{\star}$ & $0.372^{\star}$ \\
\cline { 2 - 6 } & $\mathrm{p}$ & $<0.001$ & $<0.001$ & $<0.001$ & $<0.001$ \\
\hline CST & $\mathrm{r}$ & $-0.162^{*}$ & $0.417^{*}$ & $0.320^{\star}$ & $0.376^{\star}$ \\
\cline { 2 - 6 } & $\mathrm{p}$ & $<0.001$ & $<0.001$ & $<0.001$ & $<0.001$ \\
\hline
\end{tabular}

*Significant correlation $p<0.01$; **Pearson's correlation; 'Spearman's correlation. CST: Card Sorting Test; FAS: Phonemic Verbal Fluency Test; SVF: Semantic Verbal Fluency Test.

Table 4. Multiple linear regression model of performance on executive functions tasks by age, education, occupation and income.

\begin{tabular}{|c|c|c|c|c|c|c|}
\hline Variables & & B & SE (B) & $\beta$ & p & $\mathbf{R}^{2}$ \\
\hline \multirow[t]{4}{*}{ FAS Sum of letters } & Age & -0.015 & 0.020 & -0.023 & 0.436 & 0.342 \\
\hline & Years' education & 0.946 & 0.079 & 0.469 & $<0.001^{\star *}$ & \\
\hline & Occupation & 0.366 & 0.329 & 0.042 & 0.267 & \\
\hline & Income & 0.914 & 0.234 & 0.131 & $<0.001^{\star \star}$ & \\
\hline \multirow[t]{4}{*}{ SVF } & Age & -0.057 & 0.009 & -0.181 & $<0.001^{\star \star}$ & 0.341 \\
\hline & Years' education & 0.414 & 0.037 & 0.435 & $<0.001^{\star \star}$ & \\
\hline & Occupation & 0.184 & 0.156 & 0.045 & 0.238 & \\
\hline & Income & 0.324 & 0.111 & 0.099 & $0.003^{\star \star}$ & \\
\hline \multirow[t]{4}{*}{ CST } & Age & -0.012 & 0.003 & -0.130 & $<0.001^{\star \star}$ & 0.208 \\
\hline & Years' education & 0.081 & 0.012 & 0.281 & $<0.001^{\star \star}$ & \\
\hline & Occupation & -0.014 & 0.051 & -0.012 & 0.784 & \\
\hline & Income & 0.210 & 0.037 & 0.212 & $<0.001^{\star \star}$ & \\
\hline
\end{tabular}

*^Significant correlation $\mathrm{p}<0.01$. CST: Card Sorting Test; FAS: Phonemic Verbal Fluency Test; SVF: Semantic Verbal Fluency Test.

The positive relationship of education and income and SVF was maintained, whereas age retained its negative relationship despite having a lesser impact on this cognitive variable than the other factors. Age, education and income explained $34 \%$ of the results on the SVF.

Lastly, for the CST, the negative relationship with age remained, whereas age and income were positively associated with the cognitive variable. The relationship with income was the strongest. Age, education and income explained $21 \%$ of the results on the CST.

Notably, the positive relationship of occupation with the EF variables did not persist on the linear regression model.

\section{DISCUSSION}

The objective of the present study was to investigate the predictive value of sociodemographic variables (educational level, occupation and family income) on decline in executive functions. In order to better understand this relationship, the impact of cultural and sociodemographic population variability on age-related cognitive performance must be elucidated. ${ }^{10,11}$

The distribution of gender, age and education of the study sample mirrored that of the general Brazilian population ${ }^{39}$ and also the pattern reported in other Brazilian studies. ${ }^{13}$ Thus, the present sample is sociodemographically similar to the latest 2016 report by the Brazilian 
Institute of Geography and Statistics (IBGE). The findings of this study revealed that increased age is associated with lower scores on the executive function tests. However, the relationships between sociodemographic status and scores on the same tasks were positive, indicating that better social (occupation and income) and educational status correlate with better performance on the tasks.

Similar studies have shown that performance on cognitive tasks is more strongly associated with greater occupational complexity than other variables such as education. ${ }^{13,23}$ However, the cited studies employed other assessment instruments without specific focus on EFs. Also with regard to income, the accumulation of wealth during life indicates better social and health status ${ }^{40,41}$ and can therefore be considered an indicator of health aging.

Concerning the impact of education, its neuroprotective effect on cognitive decline is supported by the literature. ${ }^{11,12,14-16,42}$ Studies show that access to higher educational levels is associated with greater scores by elderly on cognitive tasks ${ }^{12,15,42}$ involving EFs and other domains $s^{5,6,43,44}$

However, in order to determine the mutual relationship of these variables with EFs, linear regression analysis was conducted. The results showed that increased age maintained a negative effect on SVC and CST scores, whilst education and income retained a positive relationship. The negative relationship of age with the FAS test no longer remained, whereas the positive relationship of income and education was maintained, serving as predictors of better results independently of age. Occupation, despite exhibiting a positive relationship with the EF variables when analyzed alone, did not retain this relationship after inclusion in the regression analysis models.

However, it should be noted that the information on income in this study was not based on the participate alone but on the family. Hence, the participant may not be engaged in paid work, yet report a high income due to the occupations of family members. Higher family income, in turn, is indicative of greater access to education. ${ }^{45}$ These facts can explain the predictive values of better results on EF tests in groups with higher income and education.

The results also showed that the FAS was not influenced by age whereas SVF performance correlated negatively with age. A Portuguese language study showed similar results, ${ }^{46}$ perhaps explained by the sensitivity of the SVF to activity decline in brain regions with increasing age. ${ }^{46}$ The phonemic verbal fluency task requires literacy, being more strongly associated with educational level and involving other brain regions that provide support in aging. ${ }^{45}$

Measures of information processing speed and working memory can shed further light on the findings of this study, given these measures are sensitive to socioeconomic variables and may have a relationship with the results outlined. Therefore, it is envisaged that future studies can contribute further.

Finally, the results of the present study revealed that educational level and income positively influenced participants' results on EF tests, attenuating expected decline for age. However, the relationship of occupation with the cognitive variables did not persist after inclusion in the linear regression model.

Author contribution. Kenia Repiso Campanholo: text supervision and statistical analysis management. Izadora Nogueira Fonte Boa: bibliographical research, statistical analysis and writer. Flávia Cristina da Silva Araujo Hodroj: bibliographical research and writer. Gláucia Rosana Guerra Benute: intellectual supervision and orientation. Mara Cristina Souza de Lucia: intellectual supervision and orientation. Eliane Correa Miotto: intellectual supervision and orientation.

\section{REFERENCES}

1. Chan RC, Shum D, Toulopoulou T, Chen EY. Assessment of executive functions: review of instruments and identification of critical issues. Arch Clin Neuropsychol. 2008;23(2):201-16.

2. Burgess PW, Veitch E, de Lacy Costello A, Shallice T. The cognitive and neuroanatomical correlates of multitasking. Neuropsychologia. 2000; 38(6):848-63.

3. Cipolotti L, Healy C, Chan E, MacPherson SE, White M, Woollett K, et al. The effect of age on cognitive performance of frontal patients. Neuropsychologia. 2015;20(75):233-41.

4. Best JR, Miller PH. A developmental perspective on executive function. Child Dev. 2010; 81(6):1641-60.

5. Keller JB, Hedden T, Thompson TW, Anteraper SA, Gabrieli JDE, Whitfield-Gabrieli S. Resting-state anticorrelations between medial and lateral

prefrontal cortex: association with working memory, aging, and individual differences. Cortex. 2015;64:271-80.

6. Bugaiska A, Clarys D, Jarry C, Taconnat L, Tapia G, Vanneste S, Isingrini $M$. The effect of aging in recollective experience: the processing speed and executivefunctioning hypothesis. Conscious Cogn. 2007;16(4): 797-808.

7. De Vis JB, Hendrikse J, Bhogal A, Adams A, Kappelle LJ, Petersen ET. Age-related changes in brain hemodynamics; A calibrated MRI study. Hum Brain Mapp. 2015; 36(10):3973-87

8. Steffener J, Habeck CG, Stern Y. Age-related changes in task related functional network connectivity. PLoS One. 2012;7(9):e44421.

9. Hoffstaedter F, Grefkes C, Roski C, Caspers S, Zilles K, Eickhoff SB. Age-related decrease of functional connectivity additional to gray matter 
atrophy in a network for movement initiation. Brain Struct Funct. 2015; 220(2):999-1012.

10. Apolinario D, Brucki SM, Ferretti RE, Farfel JM, Magaldi RM, Busse AL, Jacob-Filho W.. Estimating Premorbid Cognitive Abilities in LowEducated Populations. PLoS One. 2013; 8(3):e60084.

11. Apolinario D, Mansur LL, Carthery-Goulart MT, Brucki SM, Nitrini R.. Detecting limited health literacy in Brazil: development of a multidimensional screening tool. Health Promot Int. 2014;29(1):5-14.

12. Branco LD, Cotrena C, Pereira N, Kochhann R, fonseca RP. Verbal and visuospatial executive functions in healthy elderly. Dement Neuropsychol. 2014;8(2):155-61.

13. Correa Ribeiro PC, Lopes CS, Lourenço RA. Complexity of lifetime occupation and cognitive performance in old age. Occup Med. 2013; 63(8):556-62

14. Steffener J, Y Stern. Exploring the neural basis of cognitive reserve in aging. Biochim Biophys Acta. 2012;1822(3):467-73.

15. Steffener J, Barulli D, Habeck C, O'Shea D, Razlighi Q, Stern Y. The Role of Education and Verbal Abilities in Altering the Effect of Age-Related Gray Matter Differences on Cognition. PLoS One. 2014;9(3):e91196.

16. Boyle PA, Yu L, Wilson RS, Segawa E, Buchman AS, Bennett DA. Cognitive decline impairs financial and health literacy among community-based older persons without dementia. Psychol Aging. 2013;28(3):614-24.

17. Zahone LB, Glymour MM, Sparks C, Bontempo D, Dixon RA, MacDonald SW, Manly JJ. Education does not slow cognitive decline with aging:12-year evidence from the Victoria Longitudinal Study. J Int Neuropsychol Soc. 2011;17(6):1039-46

18. Prince M, Acosta D, Ferri CP, Guerra M, Huang Y, Llibre Rodriguez J J, et al. Dementia incidence and mortaly in middle-incomes coutries and associations with indicatores cognitives reserve: a 10/66. Lancet. 2012; 380(9836):50-8.

19. Henderson WW. Three midlifestrategies to prevent cognitive impairment due to Alzheimer's disease. Climacteric. 2014;17(Suppl 2):38-46.

20. Sobral M, Pestanha MH, Paul C. Cognitive reserve and the severity of Alzheimer's disease. Arq Neuropsiquiatr. 2015;73(6):480-6.

21. Roldan-Tapia L, García J, Cánovas R, León I. Cognitive reserve, age, and their relation to attentional and executive functions. Appl Neuropsycho Adult. 2012;19(1):2-8

22. Duarte CMR, Pedroso MM, Bellido JG, Moreira RS, Viacava F. Regionalização e desenvolvimento humano: uma proposta de tipologia de Regiões de Saúde no Brasil. Cad. Saúde Pública. 2015; 31(6): 1163-74.

23. Singh-Manoux A, Marmot MG, Glymour M, Sabia S, Kivimäki M, Dugravot A. Does cognitive reserve shape cognitive decline? Ann Neurol. 2011;70(2):296-304.

24. Noble KG, Houston SM, Brito NH, Bartsch H, Kan E, Kuperman JM, et al. Family income, parental education and brain structure in children and adolescents. Nat Neurosci. 2015;18(5):773-8.

25. Amer MS, Mossa SM, Abdul-Rahman SA, Mabrook RA, Raafat VA. Relationship Between Socioeconomic Factors and Cognitive Function in Elderly Caregivers. J Am Geriatr Soc. 2015; 63(4):818-20.

26. Rej S, Begley A, Gildengers A, Dew MA, Reynolds CF 3rd, Butters MA. Psychosocial Risk Factors for Cognitive Decline in Late-Life Depression: Findings from the MTLD-III Study. Can Geriatr J. 2015;18(2): 43-50.

27. Nelson HE. A modified card sorting test sensitive to frontal lobe deficits. Cortex. 1976;12(4):313-24.

28. Head D, Kennedy KM, Rodrigue KM, Raz N. Age differences in perseveration: cognitive and neuroanatomical mediators of performance on the Wisconsin Card Sorting Test. Neuropsychologia. 2009;47(4):1200-3.

29. Charchat Fichman H, Fernandes CS, Nitrini R, Lourenço RA, Paradela EMP Carthery-Goulart MT, Caramelli P. Age and educational level effects on the performance of normal elderly on category verbal fluency tasks. Dement Neuropsychol. 2009;3(1):49-54

30. Strauss E, Sherman EM, Spreen O. A Compendium of Neuropsychological Tests Administration, norms and commentary. $3^{\text {a }}$. New York: Oxford: Oxford University Press, 2006

31. Tupak SV, Badewien M, Dresler T, Hahn T, Ernst LH, Herrmann MJ, et al. Differential prefrontal and frontotemporal oxygenation patterns during phonemic and semantic verbal fluency. Neuropsychologia. 2012;50(7):1565-9.

32. Brucki SMD, Nitrini R, Caramelli P, Bertolucci PHF, Okamoto $\Vdash H$. Sugestões para o uso do mini exame do estado mental no Brasil. Arq Neuropsiquiatr. 2003;61(3B):777-81.

33. Zigmond AS, Snaith RP.The hospital Anxiety and Depression Scale. Acta Psychiatr Scand. 1983;67(6):361-70.

34. Classificação Brasileira de Ocupações. Classificação Brasileira de Ocupações: Portal do Trabalho e Emprego. [Online] [Citado em: 19 de junho de 2015.] http://www.mtecbo.gov.br/cbosite/pages/informacoesGerais.jsf\#2.

35. Ringe WK, Saine KC, Lacritz LH, Hynan LS, Cullum CM. Dyadic Short Forms of the Wechsler Adult Intelligence Sacle-III. Assessment. 2002; 9(3):254-60.

36. Nascimento E. WAIS III: Escala de Inteligencia Wechsler para Adultos: Manual David Wechsler; Adaptação e padronização brasileira. $3^{a}$ edição. São Paulo: Casa do Psicólogo, 2004.

37. Monchi O, Petrides M, Petre V, Worsley K, Dagher A. Wisconsin Card Sorting revisited: distinct neural circuits participating in different stages of the task identified by event-related functional magnetic resonance imaging. J. Neurosci. 2001;21(19):7733-41.

38. Tupak SV, Badewien M, Dresler T, Hahn T, Ernst LH, Herrmann MJ, et al. Differential prefrontal and frontotemporal oxygenation patterns during phonemic and semantic verbal fluency. Neuropsychologia. 2012; 50(7):1565-9.

39. Simões CCS Relações entre as Alterações Históricas na Dinâmica Demográfica Brasileira e os Impactos Decorrentes do Processo de Envelhecimento da População. Rio de Janeiro: Instituto Brasileiro de Geografia e Estatística; 2016.

40. Xu X, Liang J, Bennett JM, Botoseneanu A, Allore HG. Socioeconomic Stratification and Multidimensional Health Trajectories: Evidence of Convergence in Later Old Age. J Gerontol B Psychol Sci Soc Sci. 2015;70(4):661-71.

41. Erickson KI, Leckie RL, Weinstein AM, Radchenkova P, Sutton BP, Prakash RS, et al. Education mitigates age-related decline in N-Acetylaspartate levels. Brain Behav. 2015; 5(3):e00311.

42. Giogkaraki E, Michaelides MP, Constantinidou F. The role of cognitive reserve in cognitive aging: results from the neurocognitive study on aging. J Clin Exp Neuropsychol. 2013;35(10):1024-35.

43. Lachman ME, Agrigoroaei S, Murphy C, Tun PA. Frequent Cognitive Activity Compensates for Education Differences in Episodic Memory. Am J Geriatr Psychiatry. 2010;18(1):4-10.

44. Miotto EC, Sato J, Lucia MCS, Camargo CHP, Scaff M. Development of an adapted version of the Boston Naming Test for Portuguese speakers. Rev Bras Psiq. 2010;32(3):279-82.

45. Ministério da Educação. Pradime: Programa de Apoio aos Dirigentes Municipais. Caderno de Textos Vol. 1, 2006.

46. Cavaco S, Gonçalves A, Pinto C, Almeida E, Gomes F, Moreira I, et al. Semantic Fluency and Phonemic Fluency: Regression-based Norms for the Portuguese Population. Arch Clin Neuropsychol. 2013;28(3):262-71.

47. Yin S, Zhu X, He R, Li R, Li J. Spontaneous Activity in the Precuneus Predicts Individual Differences in Verbal Fluency in Cognitively Normal Elderly. Neuropsychology. 2015; 29(6):961-70. 